\title{
N-Acetylneuraminic acid transport by Streptococcus oralis strain AR3
}

\author{
H. L. BYERS, K. A. HOMER, E. TARELLI and D. BEIGHTON \\ Joint Microbiology Research Unit, King's College School of Medicine and Dentistry, London, SE5 9RW
}

\begin{abstract}
Streptococcus oralis has emerged as one of the most important organisms of the viridans streptococcus group in terms of infections and is recognised as an agent of infective endocarditis and, in immunocompromised patients, septicaemia. The mechanisms by which this organism proliferates in vivo are unknown. However, host-derived sialic acids - including $\mathbf{N}$-acetylneuraminic acid (NeuNAc) which is present in serum and cellassociated glycoproteins - are a potential source of fermentable carbohydrate for bacterial proliferation, especially for sialidase-producing bacteria, including $S$. oralis. To further elucidate the role of NeuNAc in supporting growth, this study determined the ability of $S$. oralis strain AR3 (isolated from a patient with infective endocarditis) to transport NeuNAc and characterised the transport system. The transport of $\left[{ }^{14} \mathrm{C}\right]-$ labelled NeuNAc into $S$. oralis was monitored and this transport system was induced by growth of the bacteria in the presence of the $\mathrm{N}$-acetylated sugars NeuNAc, Nacetylglucosamine and $\mathrm{N}$-acetylmannosamine. The transport system followed typical Michaelis-Menten kinetics, with a $K_{m}$ of $21.0 \mu \mathrm{M}$ and a $V_{\max }$ of 2.65 nmoles of NeuNAc transported $/ \mathrm{min} / \mathrm{mg}$ of dry cell mass. NeuNAc transport was inhibited by the presence of exogenous $\mathrm{N}$-glycolylneuraminic acid, a related sialic acid. Chlorhexidine, $\mathrm{NaF}$ and 2,4-dinitrophenol were potent inhibitors of the transport system, suggesting that the uptake of NeuNAc occurs via a proton motive force-dependent permease system. This is the first report of the mechanism by which NeuNAc transport occurs in pathogenic streptococci. This transport process may have relevance to the acquisition of a source of fermentable carbohydrate and thus bacterial proliferation in vivo.
\end{abstract}

\section{Introduction}

The viridans streptococci have long been known as causative agents of infective endocarditis and are now recognised as important pathogens in immunocompromised patients and those with malignancies [1-6]. Changes in the taxonomy of this highly heterogeneous group of organisms and improvements in methods for phenotypic differentiation $[7,8]$ have enabled the association between individual species and specific diseases to be established unequivocally [9-12]. In light of these studies, it is evident that Streptococcus oralis, probably the most pathogenic species within the viridans streptococci, is often isolated as the causative agent of a majority of these infections [9, 13, 14]. Most studies on the virulence mechanisms of the viridans

Received 18 May 1998; revised version accepted 30 Aug. 1998.

Corresponding author: Dr K. A. Homer (e-mail: karen.a. homer@kcl.ac.uk). streptococci have focused on the ability of these organisms to gain entry to the host circulation $[15,16]$, to adhere to host tissue and tissue components [17-19], to bring about platelet aggregation [3, 20, 21] and to evade local host defence mechanisms via the production of immunoglobulin A protease activity [22]. However, the mechanisms by which these fermentative bacteria obtain carbohydrate for proliferation within the host have been largely ignored. The availability of a source of carbohydrate must be crucial for the survival of viridans streptococci in vivo and $S$. oralis produces an array of glycosidases, including sialidase, with the potential to cleave monosaccharides from host glycoproteins $[7,9,23-25]$.

Sialic acids occur widely throughout all kingdoms and $>30$ derivatives of the parent molecule, neuraminic acid, are currently recognised. The predominant form found in mammals is $\mathrm{N}$-acetylneuraminic acid (NeuNAc) $[26,27]$, which is found both in the free form in body fluids and as the terminal monosaccharide in 
oligosaccharide chains of glycoproteins found within the circulation and as components of host tissues. Previous studies investigated the ability of all currently recognised species of viridans streptococci to metabolise free NeuNAc and demonstrated that $S$. oralis is capable of utilising NeuNAc for growth [28]. They also demonstrated that $S$. oralis produces a sialidase with the capacity to cleave terminal NeuNAc residues from the human serum acute phase glycoprotein, $\alpha_{1}$-acid glycoprotein, and that this cleavage and subsequent utilisation of the released sugar played a role in the growth of the organism on the glycoprotein in vitro [29]. To our knowledge, bacterial transport systems for NeuNAc have been described in any detail only for Escherichia coli [30] and Lactobacillus plantarum [31]. To further clarify the role of NeuNAc in supporting growth of $S$. oralis, the present study investigated the transport of NeuNAc by $S$. oralis isolated from a patient with infective endocarditis.

\section{Materials and methods}

\section{Bacterial strain and culture}

S. oralis strain AR3 was maintained routinely by subculture on Fastidious Anaerobe Agar (LabM) supplemented with defibrinated horse blood (TCS) $5 \%$. Cultures were incubated in an anaerobic atmosphere $\left(\mathrm{N}_{2} 80 \%, \mathrm{CO}_{2} 10 \%, \mathrm{H}_{2} 10 \%\right)$ for 1 or 2 days at $37^{\circ} \mathrm{C}$. Single colonies were removed into $20-\mathrm{ml}$ volumes of pre-reduced Brain Heart Infusion Broth (BHI; Oxoid) and incubated anaerobically until cultures had attained late exponential or early stationary phase. Minimal medium, in which no growth of $S$. oralis occurred without the inclusion of a source of fermentable carbohydrate, was prepared as described previously [28] and supplemented with NeuNAc (from E. coli; Sigma) to a final concentration of $10 \mathrm{mM}$ in volumes of up to $20 \mathrm{ml}$ prepared in sterile $28-\mathrm{ml}$ screw-capped containers (Sterilin). Following pre-reduction, the minimal medium was inoculated with $5 \%$ $\mathrm{v} / \mathrm{v}$ of the BHI starter culture and incubated anaerobically; 200- $\mu$ l volumes of the culture were removed at intervals and the increase in absorbance at $620 \mathrm{~nm}$ $\left(\mathrm{A}_{620}\right)$ was determined in a 96-well plate-reading spectrophotometer (MCC340 Titerscan; ICN-Flow) as a measure of growth. Bacterial cells were harvested from late exponential phase cultures $\left(\mathrm{A}_{620}\right.$ of between 0.22 and 0.26 which is equivalent to an increase in $\mathrm{A}_{620}$ of $0.45-0.53$ in a conventional spectrophotometer with a 1-cm path-length) and used in transport assays. Where appropriate, NeuNAc in the minimal medium was replaced with glucose, mannose, $\mathrm{N}$-acetylglucosamine, galactose or $\mathrm{N}$-acetylmannosamine (all from Sigma) as the sole source of fermentable carbohydrate, each at a final concentration of $10 \mathrm{mM}$. N-Acetylgalactosamine, a constituent of O-linked glycoproteins, did not support growth of $S$. oralis when supplied as the supplement to minimal medium.

\section{Preparation of bacterial cells for transport assays}

$S$. oralis cells were harvested by centrifugation at $2700 \mathrm{~g}$ for $10 \mathrm{~min}$ at $4^{\circ} \mathrm{C}$ and the supernate was discarded. The cell pellet was resuspended in $20 \mathrm{ml}$ of chilled $50 \mathrm{mM}$ potassium phosphate buffer containing $1 \mathrm{mM} \mathrm{MgCl}_{2}$ (buffer A) and washed twice by centrifugation. The resulting pellet was resuspended in a small volume of buffer $\mathrm{A}$ and a series of dilutions was prepared to give a range of $A_{620}$ values of $0.1-0.6$. A $10-\mathrm{ml}$ sample of each suspension was filtered under vacuum through a pre-weighed nylon filter $(0.2 \mu \mathrm{m}$ pore size; Sigma) which had been soaked in buffer $A$ and the cells were washed twice with $10 \mathrm{ml}$ of buffer A equilibrated to $37^{\circ} \mathrm{C}$. The filters were dried to constant weight at $80^{\circ} \mathrm{C}$ and the dry cell mass $/ \mathrm{ml}$ of suspension was calculated; all determinations were performed in triplicate. The relationship between $A_{620}$ of the cell suspension and dry cell mass was determined $\left(\mathrm{r}^{2}=0.98\right.$ over the $A_{620}$ range $0.1-0.6$; data not shown) and the $A_{620}$ was used to adjust the cell mass in bacterial suspensions before their use in transport assays.

For transport assays, $S$. oralis cells were harvested from late exponential phase cultures and washed as described above. Chilled buffer $\mathrm{A}$ was used to adjust the $A_{620}$ of the cell suspension to give a cell concentration equivalent to $400 \mu \mathrm{g}$ dry cell mass $/ \mathrm{ml}$. The resulting cell preparations were stored on ice for the duration of the transport assays and were used within $1 \mathrm{~h}$ of preparation.

\section{Assay of NeuNAc transport by S. oralis}

The standard assay for NeuNAc transport comprised $500 \mu 1$ of washed cell suspension from NeuNAcderived cultures, $100 \mu \mathrm{l}$ of a $1 \mathrm{mM}$ aqueous solution of NeuNAc, $0.25 \mu \mathrm{l}$ of a $2 \mathrm{mM}$ solution of $\left[{ }^{14} \mathrm{C}\right]-$ labelled NeuNAc (specific activity $1.85 \mathrm{MBq} / \mu \mathrm{mol}$; Sigma) and buffer $A$ in a total volume of $1 \mathrm{ml}$. All assay components were equilibrated to $37^{\circ} \mathrm{C}$ before use in assays and the reaction was initiated by the addition of the cell suspension. Assay mixtures were incubated aerobically at $37^{\circ} \mathrm{C}$ and samples were removed for the measurement of transported NeuNAc.

To determine initial rates of NeuNAc uptake, the standard assay was scaled to a total volume of $10 \mathrm{ml}$ and $1-\mathrm{ml}$ samples were removed at intervals over a $60-$ min period. Samples were filtered under vacuum through $0.2-\mu \mathrm{m}$ pre-weighed nylon filters and washed rapidly twice with $10 \mathrm{ml}$ of buffer $\mathrm{A}$ equilibrated to $37^{\circ} \mathrm{C}$. The filters were dried to constant weight at $80^{\circ} \mathrm{C}$ and the amount of accumulated $\left[{ }^{14} \mathrm{C}\right]$-labelled NeuNAc was determined by scintillation counting. The dried filters were transferred to $10-\mathrm{ml}$ scintillation vials (Griffiths and Neilson) and $3 \mathrm{ml}$ of scintillation fluid (Ecoscint A; National Diagnostics, Hessle, Hull) were added to each. The radioactivity of the samples was determined in disintegrations/min (DPM) in a liquidscintillation counter (Tri-carb 2200CA; Canberra Pack- 
ard, Pangbourne, Berkshire). DPM values were used to calculate the number of moles of $\left[{ }^{14} \mathrm{C}\right]$-labelled NeuNAc transported and hence the total uptake of NeuNAc, as the ratio of unlabelled to labelled NeuNAc in transport assays was 200:1. All assays were performed in triplicate and rates of NeuNAc transport by $S$. oralis were calculated as nmoles of NeuNAc transported $/ \mathrm{min} / \mathrm{mg}$ of dry cell mass.

Control assays were designed to determine the actual rates of NeuNAc transport by $S$. oralis. Non-specific binding of $\left[{ }^{14} \mathrm{C}\right]$-labelled NeuNAc to the cell surface may contribute to the total radioactive count and assay systems were constructed in an attempt to determine this contribution to the measurement of NeuNAc uptake. The standard NeuNAc transport assay was performed with incubation at $37^{\circ} \mathrm{C}$ for $30 \mathrm{~min}$ to allow NeuNAc transport by $S$. oralis. At the end of this incubation period, trichloroacetic acid solution (Merck) $20 \% \mathrm{w} / \mathrm{v}$ was added to a final concentration of $10 \%$ $\mathrm{w} / \mathrm{v}$ and the assay mixture was stored on ice for 30 min. It was expected that this treatment would result in the release of surface-bound NeuNAc that had not been transported by denaturing ligands involved in binding at the cell surface. In parallel assays, buffer A replaced the trichloroacetic acid solution. Cells were filtered and transported NeuNAc was measured as described above. Non-specific binding of NeuNAc to the nylon filters was measured by filtering the standard assay mixture in which the cell suspension had been replaced by an equal volume of buffer A and washing prior to drying of the filters and scintillation counting. Finally, the background contribution of the bacterial cell suspension to the radioactive counts was determined by filtering an assay mixture from which NeuNAc had been omitted and determining the DPM. This series of experiments demonstrated that the contribution of non-specific binding of NeuNAc to the cell surface and to the nylon filters was negligible, being $<0.1 \%$ of the final radioactive count when NeuNAc transport by $S$. oralis cells was allowed to proceed to completion. No decrease in radioactive counts was observed when cells were treated with trichloroacetic acid, indicating that cell lysis under these conditions was negligible. A measurable background radioactive count due to the presence of bacterial cells was recorded and this was subtracted from the total DPM obtained for each assay to calculate the actual NeuNAc transport by $S$. oralis cells. Quenching of the radioisotope due to the presence of bacterial cells, which would lower the total measurable DPM, was not determined. As the total mass of bacterial cells was standard throughout, quenching of the radioisotope was constant and, therefore, was not considered further.

\section{Kinetics of NeuNAc transport by S. oralis}

To determine the $\mathrm{K}_{\mathrm{m}}$ and $\mathrm{V}_{\max }$ of the NeuNAc transport system of $S$. oralis, cells derived from NeuNAc- supplemented cultures were incubated in the presence of NeuNAc at concentrations ranging from $10 \mu \mathrm{M}$ to $2 \mathrm{mM}$, with the assay volume adjusted accordingly by the addition of an appropriate volume of buffer $\mathrm{A}$. The concentration of $\left[{ }^{14} \mathrm{C}\right]$-labelled NeuNAc included in assays was adjusted accordingly, so that the concentration added was always 200-fold less than the concentration of unlabelled NeuNAc. Assays were incubated at $37^{\circ} \mathrm{C}, 1-\mathrm{ml}$ samples were removed and cells were harvested, washed and DPM determined while the rate of NeuNAc uptake was still linear with respect to time.

\section{Effect of monosaccharides on the transport of NeuNAc by $S$. oralis}

The effect of the presence of glycoprotein-derived and related monosaccharides on NeuNAc transport by $S$. oralis was determined. Glucose, fucose, galactose, mannose, $\mathrm{N}$-acetylglucosamine, $\mathrm{N}$-acetylgalactosamine, $\mathrm{N}$-acetylmannosamine and $\mathrm{N}$-glycolylneuraminic acid (Sigma) were dissolved in buffer $\mathrm{A}$ to a concentration of $1 \mathrm{mM}$. Each sugar was added to the standard transport assay mixture at a final concentration of $0.1 \mathrm{mM}$, equimolar with the concentration of NeuNAc, the assays were incubated at $37^{\circ} \mathrm{C}$ and NeuNAc uptake was determined.

\section{Inhibition of the S. oralis NeuNAc transport system}

The effects of various compounds upon NeuNAc transport by $S$. oralis were determined by adding potential inhibitors to the standard transport assay mixture. Metabolic inhibitors used in the study were 2,4-dinitrophenol (2,4-DNP), chlorhexidine, sodium fluoride $(\mathrm{NaF})$, sodium azide, sodium arsenate and valinomycin (all purchased from Sigma). Chlorhexidine and 2,4-DNP disrupt the membrane potential in grampositive bacteria [32, 33]. NaF inhibits proton-translocating ATPases and enolase, the enzyme required for the conversion of 2-phosphoglycerate to PEP in the EMP glycolytic pathway [34]. Sodium azide and sodium arsenate are uncouplers of oxidative phosphorylation [35] and the antibiotic valinomycin dissipates the $\mathrm{K}^{+}$potential of the cell membrane [36]. Other compounds studied were the thiol reagents iodoacetate, dithiothreitol (DTT), cysteine hydrochloride (cys-HCI) and $\beta$-mercaptoethanol and the metal salts $\mathrm{HgCl}_{2}$, $\mathrm{ZnSO}_{4}, \mathrm{Cu}_{2} \mathrm{SO}_{4}$ and $\mathrm{AgNO}_{3}$. All compounds were prepared as aqueous solutions in buffer $\mathrm{A}$ with the exception of 2,4-DNP which was dissolved in dimethylsulphoxide. Metabolic inhibitors, thiol reagents, metal salts and valinomycin were prepared to give final concentrations of $5,5,1$ and $0.01 \mathrm{~mm}$, respectively, in transport assays. Cells were incubated at $37^{\circ} \mathrm{C}$ for $2 \mathrm{~min}$ in the presence of each compound before the addition of NeuNAc. Assays were incubated at $37^{\circ} \mathrm{C}$ and sampled for counting while NeuNAc transport was still linear with respect to time. 


\section{Results}

\section{Kinetics of NeuNAc transport by S. oralis}

Bacterial cells derived from NeuNAc-supplemented cultures, incubated at $37^{\circ} \mathrm{C}$ with $0.1 \mathrm{mM}$ unlabelled NeuNAc and $0.5 \mu \mathrm{M}\left[{ }^{14} \mathrm{C}\right]$-labelled NeuNAc at $\mathrm{pH} 7.0$, displayed a time-dependent uptake of the monosaccharide (Fig. 1). The amount of $\left[{ }^{14} \mathrm{C}\right]$-labelled NeuNAc transported by cells showed a steady increase over the first $20 \mathrm{~min}$ of the assay before reaching a plateau at $c$. 11 nmoles of NeuNAc transported/mg of dry cell mass. Experiments performed on three separate occasions to determine the reproducibility of these assays indicated that the mean rate of transport of $\left[{ }^{14} \mathrm{C}\right]$ labelled NeuNAc by $S$. oralis was 1.08 SD 0.12 nmoles of NeuNAc transported $/ \mathrm{min} / \mathrm{mg}$ of dry cell mass.

Initial rates of uptake of $\left[{ }^{14} \mathrm{C}\right]$-labelled NeuNAc were measured at different concentrations of added NeuNAc in the incubation mixture. Transport of NeuNAc followed typical Michaelis-Menten kinetics (Fig. 2) and the Hans plot indicated that the $\mathrm{K}_{\mathrm{m}}$ value for NeuNAc transport in $S$. oralis was $21.0 \mu \mathrm{M}$ and the estimated $V_{\max }$ was 2.65 nmoles of NeuNAc transpor$\mathrm{ted} / \mathrm{min} / \mathrm{mg}$ of dry cell mass.

\section{Induction of the S. oralis NeuNAc transport system}

Cells of $S$. oralis derived from glucose-, galactose- or mannose-supplemented cultures did not transport

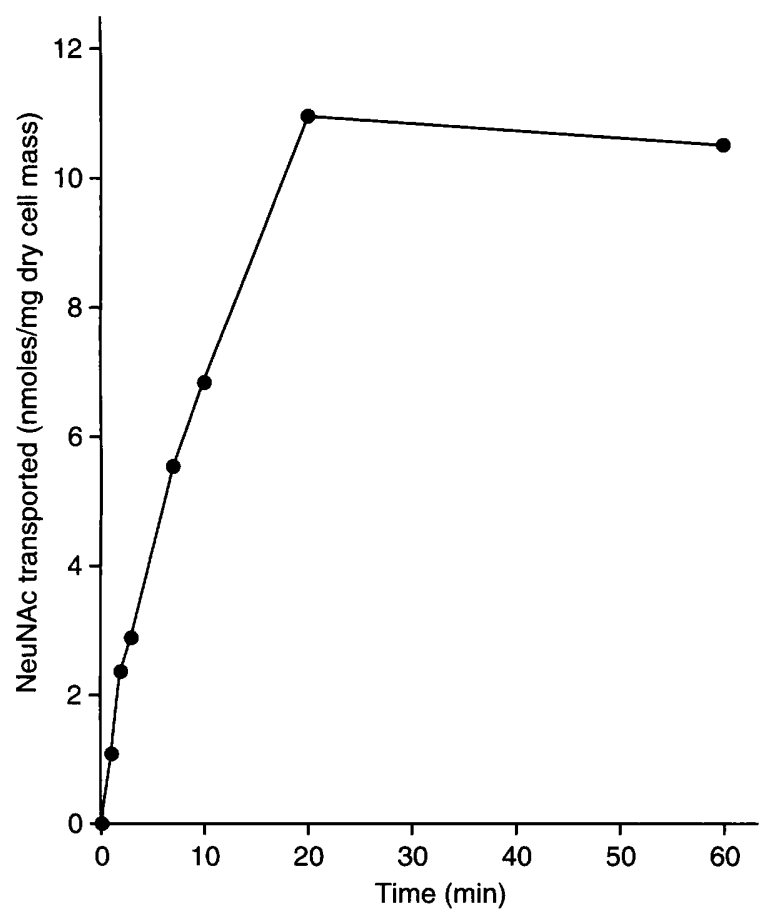

Fig. 1. Transport of NeuNAc by $S$. oralis strain AR3 as a function of incubation time. Cells harvested from NeuNAc-supplemented minimal medium were incubated at $37^{\circ} \mathrm{C}$ in the presence of $100 \mu \mathrm{M}$ NeuNAc and $0.5 \mu \mathrm{M}$ $\left[{ }^{14} \mathrm{C}\right]$-labelled NeuNAc. Data shown are the mean values of three independent experiments.

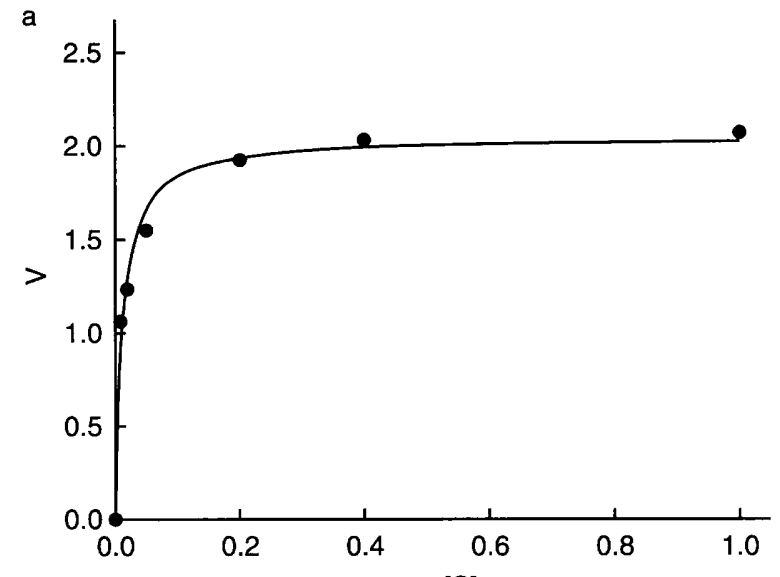

[S]

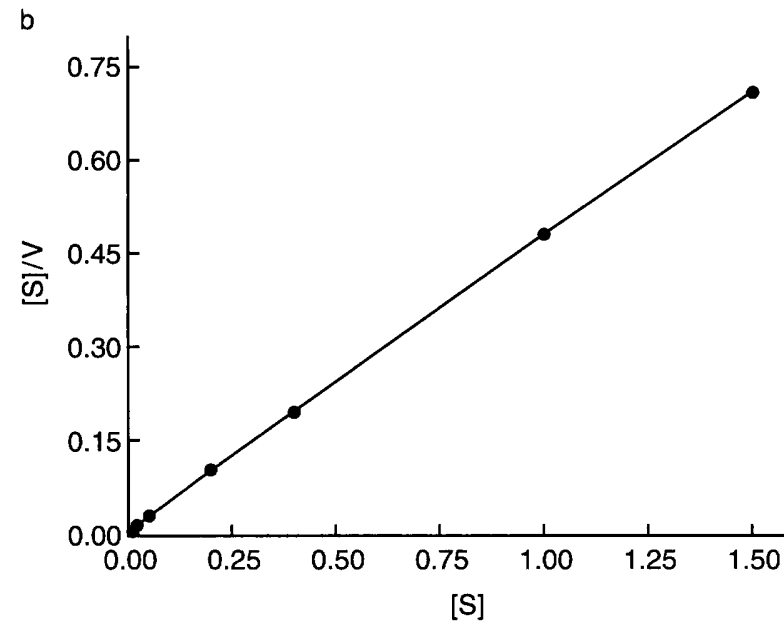

Fig. 2. Kinetics of NeuNAc transport in S. oralis strain AR3: a, Michaelis-Menten plot; b, Hans plot. The NeuNAc concentration [S] is expressed in $\mathrm{mM}$ and the reaction velocity [V] is expressed as nmoles of NeuNAc transported $/ \mathrm{min} / \mathrm{mg}$ of dry cell mass. Data shown are the mean values of three independent experiments.

NeuNAc. However, when $S$. oralis was grown in $\mathrm{N}$ acetylmannosamine- or $\mathrm{N}$-acetylglucosamine-supplemented media measurable rates of NeuNAc transport were observed. Growth in the presence of $\mathrm{N}$-acetylmannosamine or $\mathrm{N}$-acetylglucosamine induced NeuNAc transport to a level similar to that demonstrated after growth of $S$. oralis in NeuNAc-supplemented medium. Rates of transport were 1.09, 1.33 and 0.95 nmoles of NeuNAc transported $/ \mathrm{min} / \mathrm{mg}$ dry cell mass by $S$. oralis cells grown in NeuNAc-, Nacetylglucosamine and $\mathrm{N}$-acetylmannosamine-supplemented medium, respectively.

\section{Effect of monosaccharides on NeuNAc transport by NeuNAc-grown cells of $S$. oralis}

The ability of $S$. oralis to transport NeuNAc in the presence of other monosaccharides was examined and the results are shown in Table 1. The related sialic acid, $\mathrm{N}$-glycolylneuraminic acid, was the only sugar tested that had an inhibitory effect on the rate of NeuNAc transport. NeuNAc transport was inhibited by $66 \%$ by 
Table 1. Effect of exogenous monosaccharides on the NeuNAc transport system of $S$. oralis strain AR3

\begin{tabular}{lc}
\hline $\begin{array}{l}\text { Monosaccharide added } \\
\text { to transport assay }\end{array}$ & $\begin{array}{c}\text { NeuNAc transport efficiency } \\
(\% \text { of control) }\end{array}$ \\
\hline Glucose & 291 \\
Fucose & 93 \\
Mannose & 273 \\
Galactose & 92 \\
N-Acetylglucosamine & 235 \\
N-Acetylgalactosamine & 97 \\
N-Glycolylneuraminic acid & 34 \\
N-Acetylmannosamine & 95 \\
Mannitol & 104 \\
\hline
\end{tabular}

Cells harvested from NeuNAc-supplemented minimal medium were incubated at $37^{\circ} \mathrm{C}$ in the presence of $100 \mu \mathrm{M}$ NeuNAc, $0.5 \mu \mathrm{M}$ $\left[{ }^{14} \mathrm{C}\right]$-labelled NeuNAc and the indicated monosaccharides at a concentration of $100 \mu \mathrm{M}$. Rates of NeuNAc transport were determined and transport data are presented as a percentage of the rate obtained for NeuNAc in the absence of any other monosaccharide (control). Data shown are the mean values of three independent experiments.

$\mathrm{N}$-glycolylneuraminic acid, but $\mathrm{N}$-acetylmannosamine, mannitol, fucose, galactose and $\mathrm{N}$-acetylgalactosamine had a negligible effect on NeuNAc transport. However, the rate of NeuNAc transport was greatly increased in the presence of exogenous glucose, mannose and $\mathrm{N}$ acetylglucosamine, with the rate of NeuNAc transport increasing by as much as three-fold in the case of glucose.

\section{Inhibition of the NeuNAc transport system of $S$. oralis}

The effects of various compounds on the transport of NeuNAc are shown in Table 2. 2,4-DNP, chlorhexidine and $\mathrm{NaF}$, compounds which abolish the proton motive force, were potent inhibitors of NeuNAc transport,

Table 2. Effect of potential inhibitors on the NeuNAc transport system of $S$. oralis strain AR3

\begin{tabular}{lcc}
\hline Inhibitor & $\begin{array}{c}\text { Inhibitor } \\
\text { concentration } \\
(\mathrm{mM})\end{array}$ & $\begin{array}{c}\text { Inhibition of } \\
\text { NeuNAc transport } \\
(\%)\end{array}$ \\
\hline Metabolic inhibitors & & \\
Sodium azide & 5 & 16 \\
Sodium arsenate & 5 & 25 \\
2,4-DNP & 5 & 86 \\
$\mathrm{NaF}$ & 5 & 90 \\
Chlorhexidine & 5 & 81 \\
Thiol reagents & 5 & 0 \\
Cys-HCl & 5 & 0 \\
$\beta$-Mercaptoethanol & 5 & 0 \\
$\mathrm{DTT}_{\text {Iodoacetate }}$ & 5 & 77 \\
Heavy metal salts & & \\
$\mathrm{HgCl}_{2}$ & 1 & 51 \\
$\mathrm{ZnSO}_{4}$ & 1 & 31 \\
$\mathrm{Cu}_{2} \mathrm{SO}_{4}$ & 1 & 0 \\
$\mathrm{AgNO}_{3}$ & 1 & 49 \\
Valinomycin $^{2}$ & 0.01 & 0 \\
\hline
\end{tabular}

Cells harvested from NeuNAc-supplemented minimal medium were incubated at $37^{\circ} \mathrm{C}$ in the presence of $100 \mu \mathrm{M}$ NeuNAc, $0.5 \mu \mathrm{M}$ $\left[{ }^{14} \mathrm{C}\right]$-labelled NeuNAc and potential inhibitors at the indicated concentrations. Rates of NeuNAc transport were determined and percentage inhibition calculated with the rate obtained in the absence of inhibitors taken as $0 \%$ inhibition. Data shown are the mean values of three independent experiments. inhibiting transport by $86 \%, 81 \%$ and $90 \%$, respectively. Other metabolic inhibitors (sodium arsenate and sodium azide), reduced the rate of NeuNAc transport but to a lesser degree, inhibiting NeuNAc transport by $25 \%$ in the case of sodium arsenate. Valinomycin, which dissipates the $\mathrm{K}^{+}$ion potential across the cell membrane, exerted no effect on the uptake of NeuNAc by $S$. oralis.

The thiol-containing compounds, $\beta$-mercaptoethanol, cys-HCl and DTT did not affect NeuNAc transport, but the thiol-modifying reagent iodoacetate inhibited NeuNAc transport by $77 \% . \mathrm{Zn}^{2+}, \mathrm{Ag}^{2+}$ and $\mathrm{Hg}^{2+}$ ions at a concentration of $1 \mathrm{mM}$ inhibited NeuNAc transport by up to $51 \%$ (for $\mathrm{Hg}^{2+}$ ions).

\section{Discussion}

When grown in minimal medium supplemented with NeuNAc, cells of $S$. oralis strain AR3 transported NeuNAc at an appreciable rate. The transport system of NeuNAc in $S$. oralis had a $\mathrm{K}_{\mathrm{m}}$ of $12.0 \mu \mathrm{M}$, which is comparable to that of $30 \mu \mathrm{M}$ previously reported for NeuNAc transport in E. coli [30], but significantly lower than the $\mathrm{K}_{\mathrm{m}}$ of $0.24 \mathrm{mM}$ described for NeuNAc uptake in $L$. plantarum [31], indicating that the $S$. oralis transport system had a high affinity for its substrate. N-Glycolylneuraminic acid is structurally closely related to NeuNAc, with an N-glycolyl group replacing the $\mathrm{N}$-acetyl group at the $\mathrm{C}-5$ position of the parent molecule, neuraminic acid [27]. Exogenous Nglycolylneuraminic acid was an inhibitor of the transport system of $S$. oralis, suggesting that both sialic acids compete for a common transport system. Further studies are required to elucidate the mode of action of this inhibition and to determine whether $\mathrm{N}$ glycolylneuraminic acid acts as a competitive inhibitor of NeuNAc transport, and should include an investigation of the effects of varying concentrations of $\mathrm{N}$ glycolylneuraminic acid on the transport process. In addition, the ability of $S$. oralis to transport Nglycolylneuraminic acid is worthy of further investigation. Lack of inhibition of NeuNAc transport by nonsialic acid monosaccharides suggests that NeuNAc, and potentially $\mathrm{N}$-glycolylneuraminic acid, are transported by an uptake system specific for sialic acids. The transport systems of E. coli and L. plantarum are also described as being highly specific for sialic acids $[30,31]$.

The thiol-modifying reagent iodoacetate greatly reduced the rate of NeuNAc transport in $S$. oralis, which suggests that thiol groups are necessary to maintain the function of the transport system. The addition of exogenous mono- and di-thiols did not affect NeuNAc transport, indicating that the thiol groups involved in NeuNAc transport are not required in the oxidised state [37]. It can be concluded that transport of NeuNAc by $S$. oralis strain AR3 is an active process, 
as the system was inhibited by a number of established metabolic inhibitors, i.e., chlorhexidine, $\mathrm{NaF}$ and 2,4-DNP and, to a lesser degree, sodium azide and sodium arsenate. The presence of exogenous glucose, mannose and $\mathrm{N}$-acetylglucosamine in assays increased the rate of NeuNAc transport. The uptake of glucose, mannose and $\mathrm{N}$-acetylglucosamine by streptococci occurs primarily via a constitutive PEP-sugar: phosphotransferase system $[38,39]$ and will enter energy-generating pathways in the starved cells, thus fuelling NeuNAc transport. These observations support the proposal that NeuNAc transport is an energyrequiring, active process. NeuNAc transport was inhibited by $2,4-\mathrm{DNP}$, chlorhexidine and $\mathrm{NaF}$, which abolish the electrochemical potential of the cell membrane and this suggests that in $S$. oralis, NeuNAc transport proceeds via a proton motive force-dependent system. Martinez et al. [40] proposed that, in $E$. coli, NeuNAc transport also proceeds via a proton motive force-dependent sugar symport (permease) system.

NeuNAc, found in vivo as a constituent of sialylated glycoproteins and in the free form in serum and other body fluids, may provide a source of carbon to sustain bacterial growth $[41,42] . E$. coli and Clostridium perfringens have NeuNAc-specific transport systems and neuraminate pyruvate-lyase (NPL), an intracellular enzyme that cleaves NeuNAc to $\mathrm{N}$-acetylmannosamine and pyruvate. Both these activities are essential for growth of these organisms on NeuNAc and they are co-ordinately regulated $[43,44]$. An earlier study demonstrated NPL activity in $S$. oralis which was induced by growth in the presence of free NeuNAc or the highly sialylated human serum glycoprotein, $\alpha_{1}$ acid glycoprotein $[28,29]$. Both NeuNAc and $\alpha_{1}$-acid glycoprotein also induced a highly active sialidase, suggesting in conjunction with data given in the present study, that there is co-ordinate regulation of the sialidase, NeuNAc transport and NPL activities. It was proposed earlier that the further degradation of intracellular $\mathrm{N}$-acetylmannosamine in viridans streptococci proceeds, following isomerisation and phosphorylation, via the pathway of $\mathrm{N}$-acetylglucosamine catabolism, as high levels of $\mathrm{N}$-acetylglucosamine-6phosphate deacetylase and glucosamine-6-phosphate deaminase were induced following growth in the presence of NeuNAc [28]. Data presented here indicate that NeuNAc transport in $S$. oralis was induced by the $\mathrm{N}$-acetylated sugars NeuNAc, $\mathrm{N}$-acetylglucosamine and $\mathrm{N}$-acetylmannosamine, further suggesting the presence of a highly integrated regulatory system for the catabolic pathways of glycoprotein-derived NeuNAc and $\mathrm{N}$-acetylglucosamine. It has also been demonstrated previously that $S$. intermedius produces both sialidase and NPL activities when grown in the presence of mucin [45]. Furthermore, other species of viridans streptococci which are agents of human infections - including $S$. sanguis and $S$. defectivus can metabolise free NeuNAc with the induction of intracellular NPL activities [28]. The integrated systems for the transport and catabolism of NeuNAc that have been demonstrated for $S$. oralis may well be applicable to other species of viridans streptococci.

The presence of a high affinity transport system for NeuNAc in pathogenic $S$. oralis has been demonstrated. This has relevance to the physiology of the organism, because it may enable it to utilise free NeuNAc found in body fluids and, in conjunction with the sialidase, to utilise bound NeuNAc which is a major component of glycoproteins of host tissues. Viridans streptococci have emerged as significant agents of disease in immunocompromised patients where host defence mechanisms are attenuated and $S$. oralis is an important pathogen within this group. We propose that the ability to transport host-derived NeuNAc may have relevance to the growth, and hence virulence, of this organism in vivo.

We gratefully acknowledge the support of the Joint Research Committee of King's College School of Medicine and Dentistry and the British Heart Foundation (grant no. PG/95064) in funding this research.

\section{References}

1. Bochud P-Y, Calandra T, Francioli P. Bacteremia due to viridans streptococci in neutropenic patients: a review. $A m J$ Med 1994; 97: 256-264.

2. Bochud P-Y, Eggiman P, Calandra T, van Melle G, Saghafi L, Francioli P. Bacteremia due to viridans streptococccus in neutropenic patients with cancer: clinical spectrum and risk factors. Clin Infect Dis 1994b; 18: 25-31.

3. Douglas CWI. Pathogenic mechanisms in infective endocarditis. Rev Med Microbiol 1993; 4: 130-137.

4. Awada A, van ber Auwera P, Meunier F, Daneau D, Klastersky J. Streptococcal and enterococcal bacteremia in patients with cancer. Clin Infect Dis 1992; 15: 33-48.

5. Cohen J, Donnelly JP, Worsley AM, Catovsky D, Goldman JM, Galton DAG. Septicaemia caused by viridans streptococci in neutropenic patients with leukaemia. Lancet 1983; 2: 14521454.

6. McWhinney PH, Patel S, Whiley RA, Hardie JM, Gillespie $\mathrm{SH}$, Kibbler $\mathrm{CC}$. Activities of potential therapeutic and prophylactic antibiotics against blood culture isolates of viridans group streptococci from neutropenic patients receiving ciprofloxacin. Antimicrob Agents Chemother 1993; 37: 24932495.

7. Beighton D, Hardie JM, Whiley RA. A scheme for the identification of viridans streptococci. J Med Microbiol 1991; 35: $367-372$.

8. Kilian M, Mikkelsen L, Henrichsen J. Taxonomic study of viridans streptococci: description of Streptococcus gordonii sp. nov. and emended descriptions of Streptococcus sanguis (White and Niven 1946), Streptococcus oralis (Bridge and Sneath 1982), and Streptococcus mitis (Andrewes and Horder 1906). Int J Syst Bacteriol 1989; 39: 471-484.

9. Beighton $\mathrm{D}$, Carr $\mathrm{AD}$, Oppenheim BA. Identification of viridans streptococci associated with bacteraemia in neutropenic cancer patients. $J$ Med Microbiol 1994; 40: $202-204$.

10. Whiley RA, Beighton D, Winstanley TG, Fraser HY, Hardie JM. Streptococcus intermedius, Streptococcus consellatus, and Streptococcus anginosus (the Streptococcus milleri group): association with different body sites and clinical infections. $J$ Clin Microbiol 1992; 30: 243-244.

11. Jacobs JA, Schouten HC, Stobberingh EE, Soeters PB. Viridans streptococci isolated from the bloodstream. Relevance of species identification. Diagn Microbiol Infect Dis 1995; 22: 267-273.

12. Hardie JM, Whiley RA. Recent developments in streptococcal 
taxonomy: their relation to infections. Rev Med Microbiol 1994; 5: $151-162$

13. Douglas CWI, Heath J, Hampton KK, Preston FE. Identity of viridans streptococci isolated from cases of infective endocarditis. J Med Microbiol 1993; 39: 179-182.

14. Bouvet A, Durand A, Devine C, Etiènne J, Leprot C, Groupe D'Enquête sur l'Endocardité en France en 1990-1991. In vitro susceptibility to antibiotics of 200 strains of streptococci and enterococci isolated during infective endocarditis. In: Totolian A (ed) Pathogenic streptococci: present and future. Proceedings of the XII Lancefield International Symposium of Streptococci and Streptococcal Diseases. St Petersberg, Russia, Lancer Publications. 1994: 72-73.

15. Heimdahl A, Mattsson T, Dahllof G, Lonnquist B, Ringden $O$ The oral cavity as a port of entry for early infections in patients treated with bone marrow transplantation. Oral Surg Oral Med Oral Pathol 1989; 68: 711-715.

16. Ruoff KL. Streptococcus anginosus ("Streptococcus milleri") the unrecognized pathogen. Clin Microbiol Rev 1988; 1: 102108

17. Crawford I, Russell C. Comparative adhesion of seven species of streptococci isolated from the blood of patients with subacute bacterial endocarditis to fibrin-platelet clots in vitro. $J$ Appl Bacteriol 1986; 60: 127-133.

18. Scheld WM, Valone JA, Sande MA. Bacterial adherence in the pathogenesis of endocarditis. J Clin Invest 1978; 61: 13941404.

19. Gossling J. Occurrence and pathogenicity of the Streptococcus milleri group. Rev Infect Dis 1988; 10: 257-285.

20. Douglas CWI, Brown PR, Preston FE. Platelet aggregation by oral streptococci. FEMS Microbiol Lett 1990; 60: 63-67.

21. Baddour LM. Virulence factors among Gram-positive bacteria in experimental endocarditis. Infect Immun 1994; 62: $2143-$ 2148

22. Reinholdt J, Tomana M, Mortensen SB, Kilian M. Molecular aspects of immunoglobulin Al degradation by oral streptococci. Infect Immun 1990; 58: 1186-1194.

23. Rafay AM, Homer KA, Beighton D. Effect of mucin and glucose on proteolytic and glycosidic activities of Streptococ cus oralis. J Med Microbiol 1996; 44: 409-417.

24. van der Hoeven JS, Camp PJ. The use of lectins in monitoring degradation of oligosaccharide chains in mucin by oral streptococci. Caries Res 1994; 28: 257-261.

25. van der Hoeven JS, Camp PJ. Synergistic degradation of mucin by Streptococcus oralis and Streptococcus sanguis in mixed chemostat cultures. J Dent Res 1991; 70: 1041-1044.

26. Schauer R. Origin and biological role of the great chemical diversity of natural sialic acids. Trends Glycosci Glycotech 1997; 9: 315-330.

27. Schauer R, Kelm S, Reuter G, Roggentin P, Shaw L. Biochemistry and role of sialic acids. In: Rosenberg A (ed) Biology of the sialic acids. New York, Plenum Press. 1995: $7-$ 67.

28. Byers HL, Homer KA, Beighton D. Utilization of sialic acid by viridans streptococci. J Dent Res 1996; 75: 1564-1571.

29. Homer KA, Kelley S, Hawkes J, Beighton D, Grootveld MC Metabolism of glycoprotein-derived sialic acid and $\mathrm{N}$-ace- tylglucosamine by Streptococcus oralis. Microbiology 1996; 142: $1221-1230$.

30. Rodriguez-Aparicio LB, Reglero A, Luengo JM. Uptake of Nacetylneuraminic acid by Escherichia coli K-235. Biochemical characterization of the transport system. Biochem $J$ 1987; 246: 287-294.

31. Andreadaki FJ, Kolisis FN, Sakellaris G, Evangelopoulos E. Incorporation studies of free $\mathrm{N}$-acetylneuraminic acid and cytidine monophosphate-N-acetylneuraminic acid by intact cells of Lactobacillus plantarum. Biotechnol Appl Biochem 1990; 12: 653-660.

32. Joshi AK, Ahmed S, Ames GF-L. Energy coupling in bacterial periplasmic transport systems. Studies in intact Escherichia coli cells. J Biol Chem 1989; 264: 2126-2133.

33. Kuyyakanond T, Quesnel LB. The mechanism of action of chlorhexidine. FEMS Microbiol Lett 1992; 79: 211-215.

34. Sutton SVW, Bender GR, Marquis RE. Fluoride inhibition of proton-translocating ATPases of oral bacteria. Infect Immun 1987; 55: 2597-2603.

35. Parnes JR, Boos W. Energy coupling of the $\beta$-methylgalactoside transport system of Escherichia coil. J Biol Chem 1973; 248: $4429-35$.

36. Kashket ER, Wilson TH. Proton-coupled accumulation of galactoside in Streptococcus lactis 7962. Proc Natl Acad Sci USA 1973; 70: 2866-2869.

37. Morgan MS, Darrow RM, Nafz MA, Varandani PT. Participation of cellular thiol/disulphide groups in the uptake, degradation and bioactivity of insulin in primary cultures of rat hepatocytes. Biochem $J$ 1985; 225: 349-356.

38. Liberman ES, Bleiweis AS. Transport of glucose and mannose by a common phosphoenolpyruvate-dependent phosphotransferase system in Streptococcus mutans GS5. Infect Immun 1984; 43: $1106-1109$.

39. Homer KA, Patel R, Beighton D. Effects of N-acetylglucosamine on carbohydrate fermentation by Streptococcus mutans NCTC 10449 and Streptococcus sobrinus SL-1. Infect Immun 1993; 61: 295-302

40. Martinez J, Steenbergen S, Vimr E. Derived structure of the putative sialic acid transporter from Escherichia coli predicts a novel sugar permease domain. J Bacteriol 1995; 177: 60056010 .

41. Corfield T. Bacterial sialidases - roles in pathogenicity and nutrition. Glycobiology 1992; 2: 509-521.

42. Godoy VG, Dallas MM, Russo TA, Malamy MH. A role for Bacteroides fragilis neuraminidase in bacterial growth in two model systems. Infect Immun 1993; 61: 4415-4426.

43. Nees $S$, Schauer $R$. Induction of neuraminidase from Clostridium perfringens and the co-operation of this enzyme with acylneuraminate pyruvate-lyase. Behring Inst Mitt 1974; 55: $68-78$.

44. Vimr ER, Troy FA. Identification of an inducible catabolic system for sialic acids (nan) in Escherichia coli. $J$ Bacteriol 1985 ; 164: 845-853.

45. Homer KA, Whiley RA, Beighton D. Production of specific glycosidase activities by Streptococcus intermedius strain UNS35 grown in the presence of mucin. $J$ Med Microbiol 1994; 41: 184-190. 